\title{
RECENT DEVELOPMENTS IN THE OIL INDUSTRY OF RUMANIA
}

$I^{\mathrm{T}}$

$T$ is rare indeed these days that an opportunity occurs to obtain first-hand information of contemporary developments, both technical and economic, of a major industry in an 'Iron Curtain' country, more especially when this is presented in English and, perhaps what is even more surprising, by means of an elaborate series of photographs surveying indoor and outdoor activities within that industry. That this has been most successfully achieved in the case of the oil industry in Rumania is attested by a recent publication entitled Oil-Natural Gas-Petrochemistry in Rumania*. The purpose of this publication is adequately summed up in the introduction: "The present album includes a brief survey of the development of the Rumanian oil industry, as well as facts and figures related to its present-day evolution; the photosrepresenting the images of the main sectors of the oil and petrochemical industry and socio-cultural achievements in this field-illustrate the upsurge taken in recent years by the oil industry as well as its future prospects". The photographs, in black-and-white and in colour, are excellent; they account for considerably more space than the descriptive text, the latter being essentially brief summaries of progress over the years, but with obvious emphasis on what has happened since the advent of the Rumanian People's Republic.

"A Brief History of the Rumanian Oil Industry" is the first heading; this traces events back to 1857 when production of kerosene was in fact the industry as then established, the first kerosene refinery plant being built near Ploiesti, while Bucharest, the eapital, was the first town in the world to be illuminated with kerosene. The gasolene stage dates from 1896 with production from oilextraction pits about $250 \mathrm{~m}$ dsep. With introduction of mochanical methods of drilling, oil production steadily rose, to by seriously interrupted by the First and later the Second World Wars. Nationalization of the industry began in 1948 and this is proclaimed ". . . the starting point for the impetuous development of the oil industry in Rumania". The second heading, "Well Drilling and Oil and Gas Production", records the fact that, compared with the crude oil production of Rumania for 92 years before 1948 , " . . in 15 years alone (1949-1963) more than 145 million tons were produced, i.e., some 90 per cent of the overall production before nationalization". Modern geological and geophysical methods greatly contributed to the discovery and exploitation of new and rich oil and natural gas pools in Oltenia, Western Wallachia and Moldova. Apart from oil, methane has proved one of the richest natural resources of the country; its occurrence is widespread and at 99.4 per cent pure methane it is claimed that Rumanian natural gas is unique in this respect throughout the world; output at 10,387 million $\mathrm{m}^{3}$ of methane in 1963 was at that time a record for the country; since then, to meet industrial and household demands for the gas, the methane transportation pipeline network is being expanded to $4,000 \mathrm{~km}$.

The section on "The Oil-Processing Industry and Petrochemistry" notes that, in recent years, important units for processing crude oil have been commissioned, among which are specifically mentioned the refineries at Dărmănesti and Onesti in Moldova, the oil plant at the Teleajen refinery, and the catalytic reforming complex at the Brazi refinery. In the petrochemical field, the oil industry now produces (from methane, etc.) ammonia, high-concentration nitric acid, ammonium nitrate, methanol, formaldehyde, urea and acotylene; from tho urea, aminoplasts and adhesives for the wood-processing industry are obtrined. The range of methane carbon blacks

* Oit-Natural Gas-Petrochemistry in Rumania. Edited by A. S. Banciu, Ana Georgescu, M. Portarescu and S. Sigartau. Pp. 146. (Bucharest: Meridiane Publishing House, 1965.) has been increased and a polymethacrylic resin 'Stiplex' is now in production. Further petrochemical plants are being built, to include new nitrogen fertilizer plants, plastics production, for example, polyvinyl chloride, polyethylene and polypropylene, polystyrene, phenolformaldehyde resins, polyurethanes, etc.; manufacture of synthetic yarns and fibres is being developed, as also is Rumania's synthetic rubber output based on oil gas; and the 'Danubiana' factory in Bucharest is geared to a production of $1 \cdot 1$ million car and tractor tyres in 1965 .

Under the heading "Research Work and Designing in the Oil Industry" the 'indoor' activities of more than 3,000 research workers and designers are briefly discussed; the relevant centres include: the Research Institute for Oil Drilling and Extraction at Cîmpina; a Designing Institute for Oil-wells at Ploieşti; a Designing Institute for the Oil-Processing Industry, again at Ploiești ; here also is the Petrochemical Research Institute; and there is a Research Institute for the Chemical Utilization of Methane at Mediass. Photographs of some of the laboratories concerned, equipment, apparatus, pilot plants, etc., leave little room for doubt as to the modern set-up and efficiency of this more academic aspect of the industry.

"Rumania -an Exporter of Oilfield Equipment and Oil Products" is the title of a section of this album devoted to commercial interests of the industry in its trade with other countries. We learn that Rumania now has commercial relations with more than 40 countries as regards its oil products and that new export markets are being opened up in Europe, Asia, Africa and Latin America. Rumania has built a 750,000-ton oil/year refinery at Gauhati, Assam State, India; it claims that "Rumania is now able to design and deliver the necessary equipment and plants for modern refineries of any capacity, working on any raw matorial and turning out any required product"; her co-operation with the oil industry in Afghanistan, Bulgaria, Burma, Ghana, Indonesia and the United Arab Republic is also noted.

No communication from a Communist country would, be complete without some reference to cultural facilities and this publication ends with a section, fully illustrated, dealing with "Living Conditions of Oilworkers". The information given here is impressive, particularly as regards housing accommodation and conditions, social amenities, education, medical care, and recreation. In these respects the industry is true to the modern conception of care of all people concerned in its development and progress, as is such a traditional feature now of the major oil companies operating all over the world. It would indeed be interesting, if not instructive, if only half the information contained in this book were available in the same form from other oil-producing countries behind the 'Iron Curtain'; the aid that such reading (and in this case seeing as well) imparts to better understanding of these countries is both ethically and technically incalculable.

Not content, however, with this challenging essay into world publicity, 1965 sees the first issue of a new official bulletin entitled Chemistry, Oil and Gas in Rumania $\dagger$. Here again the purpose is abundantly clear: to keep the Rumanian oil industry in the forefront of technical and commercial developments and to spread its potentialities world wide. This bulletin is also printed in English; whether in other languages is not disclosed. A synopsis of the contents of Vol. 1, No. 1, is indicative of its scope, which doos in fact spread the net wider than just the oil industry. "... the interested circles will find surveys $\dagger$ Chemistry, Oil and Gas in Rumania: News and Commentaries, No. 1, si Chimiei, 1965.) 
of the articles published in the speciality journals, news related to the research and designing activity, brief plant information, trade notes and statements of visitors of our oil and chemical sector as well as other materials illustrating the steady progress witnessed by the Rumanian oil and chemical industries". It is significantly added that this Centre will supply, on demand, "articles, summaries and other additional information translated into one of the international languages, accompanied by photos". This bulletin is in mimeograph type with no illustrations save coloured advertisements on the inside covers; but the contents - research and design, short news, commercial information, patents-books and reviews, etc., if this pattern is followed in future issues are bound to attract attention and to command a keenly interested following of international oil technologists.
H. B. MILNER

\section{ATOMIC ENERGY IN AUSTRALIA}

$\mathrm{T}$ HE twelfth annual report of the Australian Atomic Energy Commission*, for the year ending June 30, 1964 , deals with the production of uranium in Australia, research activities at the Lucas Heights Research Establishment and in Australian universities, and generally with international relationships and nuclear power developments in various countries.

The financial statement records that capital expenditure was reduced by some $£ A 175,000$, but that research expenditure increased by about £A270,000 to nearly £A3 million, largely because of the introduction of improved salary scales for the staff and the increased cost of recruitment of staff. The net operating and capital expenditure for the year was $£ A, 3,473,862$, an increase of $£ A, 287,000$ over the previous year. The advance to the Rum Jungle Project was reduced, however, from $£ A 1.58$ million to $£ A 720,000$.

Uranium continued to be in over-supply throughout the world, but the major cut-backs in production required to stabilize the industry in the Western World are now completed. It is expected that since output will continue to fall as individual mines close down, no additional drastic changes will be necessary, and that in the early 1970's world requirements for nuclear fuel will increase again quite rapidly. During 1963 about 1,200 short tons of uranium oxide were produced and sales during this period were valued at approximately $£ A 5 \cdot 5$ million. Only one sales contract remained in operation in June 1964, and although the United Uranium N.L. expected to complete production during 1964, the final deliveries under the £A5 million contract with the United Kingdom Atomic Energy Authority will extend into 1965. Treatment of stockpiled uranium ore at Rum Jungle is expected to continue at the present level for several years.

The Commission's main research programme is devoted to the investigation of the technical and economic feasibility of a high-temperature, carbon dioxide-cooled, beryllium oxide-moderated, power reactor of the pepple-bed type. The fuel elements consist of a dispersion of thorium oxide and commercial plutonium oxide in beryllia, and the core of the reactor comprises a large number of spheres or pepples, about 1 in. in diameter, of the fuel material. Four different engineering designs of the reactor system are being studied and these are shown diagrammatically in the annual report. Although considerable effort has been devoted to the various engineering and theoretical physics problems involved, including the development of computer codes for core nuclear studies, the Commission specifically states in the report that there is no commit. ment to construct a power reactor in Australia.

At the Lucas Heights Research Establishment the high ngutron flux materials testing reactor, Hifar, continued operation at a power output of 11-MW (thermal) on a 28-day cycle for the whole year, except for a two-month major overhaul period. The small low-power reactor, Moata, was used mainly for experiments associated with the performance of systems moderated with beryllium oxide. Alterations were made in the control rod read-out

* Australia. Twelfth Annual Report of the Australian Atomic Energy Commiseion for the year ended 30th June, 1964 Pp. 80. (Coogee, N.S.W. Australian Atomic Energy Commission, 1964.) system, and to the internal graphite reflector. New facilities completed or installed at the Establishment included a large single cell capable of remote-handling of up to $600,000 \mathrm{c}$. of cobalt- 60 , and a $3 \cdot \mathrm{MeV}$ positive ion Van de Graaff accelerator for fast neutron physics experimonts.

The Establishment maintained a good safety record during the year. No serious accident, either radiological or industrial, occurred. A wide range of radioisotopes was produced for use in medicine, research, agriculture and industry, and in addition to supplying Australian requirements, radioisotopes were exported to Japan, India, New Zealand. South Africa and the Philippines. The development of sources of gamma-excited monoenergetic X-rays and their application in industry were given particular attention. Special projects included the production of sources of caesium-134 and thulium-170 for radiographic purposes, and the investigation of the effects of neutron- and gamma-radiation on non-metallic bonding materials such as epoxy resin. Large sources of high specific activity of cobalt-60 can be produced in Hifar, and during the year the Commission supplied the Royal Adelaide Hospital with a 1,300-c. source, the Royal North Shore Hospital in Sydney with a 2,160-c. source, and under the Colombo Plan, the Cancer Institute of Madras, India, with a 3,025-c. source. The only significant change during the year in the demand for specific radioisotopes was an increased request for radiography sources in smaller sizes and cylindrical sources of iridium-192 of $1-\mathrm{mm}$ length and $1-\mathrm{mm}$ diameter with an activity of up to $8 \mathrm{c}$., and similar sources of cobalt-60 with an activity of $1.5 \mathrm{c}$. were produced to meet this requirement.

The first intermational conference on "Beryllium-oxide", attended by scientists from six countries, was held in Newport, New South Wales, during October 21-25, 1963. The conference was sponsored and organized by the Commission, and 56 papers were presented for discussion, including 27 from the Australian Atomic Energy Commission Research Establishment. The topics discussed covered aspects of fabrication, structure, physical and mechanical properties, radiation damage and gas-solid interactions. The last day of the conference was devoted to a symposium on the utilization of beryllium oxide in reactors. The proceedings of the conference have been published in a special issue of the Journal of Nuclear Materials (1964). In addition to a wide range of booklets, leaflets and other publications on atomic energy, the Commission also published a quarterly journal, Atomic Energy in Australia, a quarterly Radioisotope Newsletter, and a special 55-page booklet entitled $A n$ Introduction to Nuclear Science for use in schools. The Commission's film "Atoms for Everyday" was shown on the national television network and a major exhibition, "Australia and the Atom", featuring many aspects of atomic research, production and mining of uranium, nuclear power and the use of radioisotopes, was presented in Brisbane and Newcastle. The Research Establishment held open days during September 26-28, 1963, and some 6,000 persons visited and inspected it.

Research contracts totalling more than 1 A51,000 were placed with Australian universities. Details of these are 